\title{
Effect of organic pig production systems on performance and meat quality
}

\author{
L.L. Hansen ${ }^{\mathrm{a}, *}$, C. Claudi-Magnussen ${ }^{\mathrm{b}}$, S.K. Jensen ${ }^{\mathrm{c}}$, H.J. Andersen ${ }^{\text {a }}$ \\ a Department of Food Science, Danish Institute of Agricultural Sciences (DIAS), Research Centre Foulum, P.O. Box 50, DK-8830 Tjele, Denmark \\ ${ }^{\mathrm{b}}$ Danish Meat Research Institute, Maglegårdsvej 2, DK-4000 Roskilde, Denmark \\ ${ }^{\mathrm{c}}$ Department of Animal Health, Welfare and Nutrition, Danish Institute of Agricultural Sciences (DIAS), Research Centre Foulum, \\ P.O. Box 50, DK-8830 Tjele, Denmark
}

Received 7 May 2005; received in revised form 10 February 2006; accepted 24 February 2006

\begin{abstract}
The present study was carried out to establish knowledge of consequence for setting up guidelines of importance for production of competitive organic pork of high quality. Performance and meat quality characteristics were compared between three organic pig production systems based on indoor housing with access to an outdoor area and a Danish conventional indoor system including $100 \%$ concentrate during the finishing feeding stage.

The three organic systems used the following three feeding regimes: $100 \%$ organic concentrate according to Danish recommendations, $70 \%$ organic concentrate (restricted) plus ad libitum organic barley/pea silage and $70 \%$ organic concentrate (restricted) plus ad libitum organic clover grass silage, respectively.

With exception of a slightly lower daily gain in organic pigs fed $100 \%$ concentrate, no significant difference was found in performance and meat quality characteristics compared with results obtained in the conventional system. In contrast and independent of roughage used, organic pigs raised on $70 \%$ concentrate had a significant reduction in daily gain $(P<0.001)$ compared with pigs raised on $100 \%$ concentrate, despite the fact that no difference in feed conversion rate was seen between the tested production systems. However, the percentage of leanness increased significantly in meat from organic pigs raised on $70 \%$ concentrate plus roughage compared with meat from pigs given $100 \%$ concentrate. This was reflected in higher yield (weight) of lean cuts and lower yield of cuts with high fat content from pigs fed $70 \%$ concentrate plus roughage. In general, organic feeding resulted in a significantly higher content of polyunsaturated fatty acids in the back fat $(1.8 \%)$, which increased further when restricted feeding plus roughage (4\%) was used. Restricted concentrate feeding gave rise to a decrease in tenderness compared with pork from pigs fed $100 \%$ concentrate.
\end{abstract}

(C) 2006 Published by Elsevier Ltd.

Keywords: Organic; Pig; Production systems; Performance; Pork; Quality; Yield

\section{Introduction}

Extensive pig production systems, e.g., free-range production or other forms of enriched production, have gained increasing interest in Europe and North America (Bridi, Müller, \& Ribeiro, 1998; Dworschak et al., 1995; Enfält,

\footnotetext{
* Corresponding author. Present address: Department of Animal Product Quality, Danish Institute of Agricultural Sciences, Research Centre Foulum, P.O. Box 50, DK-8830 Tjele, Denmark. Tel.: +45 8999 1255; fax: +458999 1564 .

E-mail address: LauritsLydehoj.Hansen@agrsci.dk (L.L. Hansen).
}

Lundstrom, Hansson, Lundeheim, \& Nystrom, 1997; Lebret et al., 1998; Sather, Jones, Schaefer, Colyn, \& Robertson, 1997).

Beside a few traditional pig production systems, e.g., Iberian pig production in La Dehesa (Lopez-Bote, Diestre, \& Monfort, 1998), a change from confinement to enriched systems including aspects of free-range will be a challenge in a pig production, which is being constantly modernised, as pointed out in several papers (Jakobsen and Hermansen, 2001; Lopez-Bote and Rey, 2001; Lopez-Bote et al., 1998; Nilzen et al., 2001). 
Organic pig production is one of the enriched systems, which has attracted most attention in Denmark. Subsidized change from confinement to organic pig production during the last years of the past century has established a certain potential in Denmark. However, throughout the period 2001-2004, the market share of organic pork was only around $0.5-0.6 \%$ without any tendency to increase much further. Consequently, the recent demand for high quality organic pork in the UK and at the German market (Hamm \& Gronefeld, 2004) has been followed with great interest in Denmark.

Previous Danish studies have shown that conventional pork is often more tender than pork from organic pork production systems (Danielsen, Hansen, Møller, Bejrholm, \& Nielsen, 2000). This has been suggested to be due to lower daily gain in organic production (Danielsen et al., 2000), which is known to decrease the proteolytic potential of the muscle at the time of slaughter (Therkildsen, Melchior Larsen, Bang, \& Vestergaard, 2002). Moreover, the amount of intramuscular fat in organic pork has been reported to be higher (Sundrum, Butfering, Henning, \& Hoppenbrock, 2000), and the fatty acid composition to be more unsaturated compared with meat from traditionally reared pigs (Claudi-Magnussen, 1999; Hansen, Bejerholm, Claudi, \& Andersen, 2000; Nilzen et al., 2001). This may result in inferior technological meat quality due to enhanced lipid oxidation and presence of soft fat (Lopez-Bote et al., 1998; Nilzen et al., 2001; Warnants, Oeckel, Boucque, \& van-Oeckel, 1996; Warnants, Van Oeckel, \& Boucque, 1998). The vitamin E content has been shown to be higher in pork from outdoor-reared organic pigs with access to grass compared with indoor-reared pigs (Hansen et al., 2000; Nilzen et al., 2001). However, the difference is not expected to be high enough to compensate for the higher level of polyunsaturated fatty acids in relation to the oxidative stability of the meat. In contrast to these non-superior quality traits, meat from organically reared pigs has been reported to have an increased lean yield (Sather et al., 1997; Sundrum et al., 2000) and higher wholesale carcass value due to heavier loins and hams compared with pork from pigs in a confinement system (Sather et al., 1997).
Above data clearly support that differences in carcasses and pork from "new" production systems like organic pig production are not due to the rearing system alone; genetic factors, feeding and pre-slaughter handling have all to be considered as stated by Jaturasitha, Scheeder, and Kreuzer (1998).

Consequently, introduction of organic pig production systems calls for establishment of quality assurance programs that ensure production of high quality pork, as demanded by the organic consumer segment.

The present study was carried out to establish initial guidelines for organic pig producers in the production of high quality pork considering that pen systems with access to out-door area are going to be the most cost effective systems, and that roughage based on either barley/pea silage or clover/grass silage will be the most dominating in Denmark. The effect of the tested organic feeding strategies on production results and overall pork quality is compared with equal data from a typical conventional pig production system known to give rise to high quality pork.

Therefore, the objective of this project is to contribute to the development of economically profitable farming systems for production of high quality organic pork.

\section{Materials and methods}

\subsection{Animals and experimental design}

The experiment (Table 1) comprised four trials with two experimental pen replicates of each of the four treatments: Treatment A (conventionally reared Danish pigs fed 100\% concentrate according to Danish recommendations (without roughage and outdoor area)) was compared with three different organic pig production systems with access to outdoor area, where the pigs were fed either Treatment B ( $100 \%$ organic concentrate according to Danish recommendations (without roughage) $), \mathrm{C}(70 \%$ organic concentrate according to Danish recommendations (restrictedly) plus ad libitum organic barley/pea silage) or $\mathrm{D}(70 \%$ organic concentrate according to Danish recommendations (restrictedly) plus organic ad libitum clover grass silage, where the relative levels of concentrate feeding refer to an

Table 1

The experimental treatments

\begin{tabular}{|c|c|c|c|c|}
\hline Treatment & A & $\mathrm{B}$ & $\mathrm{C}$ & $\mathrm{D}$ \\
\hline Concentrate type & Conventional & Organic $^{\mathrm{a}}$ & Organic & Organic \\
\hline Concentrate feeding level according to scale & $100 \%$ ad libitum & $100 \%$ ad libitum & $70 \%$ & $70 \%$ \\
\hline Roughage type ad libitum & None & None & Barley/pea silage & Clover grass sil. \\
\hline Outdoor area & - & + & + & + \\
\hline No. of pigs per treatment & 40 & 40 & 40 & 40 \\
\hline No. of summer trials & 2 & 2 & 2 & 2 \\
\hline No. of pen replicates per treatment totally & 8 & 8 & 8 & 8 \\
\hline
\end{tabular}

\footnotetext{
${ }^{\text {a }}$ Organic treatment, but without roughage.
} 
age-related scale). The four experimental trials (replicates) consisted of two summer trials - trials 1 and 3 - in 1999 and 2000, and two winter trials - trials 2 and 4 - in 2000 and 2001. Each pen contained 5 pigs selected according to treatment, initial weight, pen replicate, litter, and sex, resulting in 160 Duroc $\times$ Danish Landrace $\times$ Large White (DLY) crossbred pigs. Of these only 152 pigs were included in the statistical analyses, as 8 animals were discarded during production and slaughtering. Two were discarded due to sickness and death and 6 due to wrong experimental treatment. Of these 6 pigs, 4 were discarded due to mixing pigs from two treatments in a pen after weighing during the final production period and 2 due to wrong experimental treatment during the slaughter process. Each trial consisted of two pen replicates per treatment, and contained 3 castrates and 2 females in one pen and 2 castrates and 3 females in the other pen.

The relative levels of concentrate feeding refer to a scale based on a time span from the start of the treatment at $40 \mathrm{~kg}$ live weight, and the $100 \%$-concentrate pigs were fed to appetite twice a day in a trough, which was emptied 30 min after start of feeding time (Madsen, Petersen, \& Soegaard, 1990). The pigs were slaughtered at approximately $108 \mathrm{~kg}$ live weight. The organically raised pigs in Treatments C and D were fed different kinds of roughage (barley/pea silage and clover grass silage, respectively) to appetite twice a day, in the first two trials from a trough and in the last two trials from a newly designed roughage hedge placed on the fence in the outdoor concrete area in order to decrease waste of roughage in the outdoor (dunging) area. The amount of roughage eaten per pen per day in Treatments $\mathrm{C}$ and $\mathrm{D}$ was calculated by subtracting the weight of the roughage left in the trough or roughage hedge from what was offered. New roughage was given each day, and the old roughage was removed. The roughage hedge used in the last two trials decreased the amount of roughage waste compared with trough feeding. Treatments B, C and D pigs were kept in accordance with the European
Community standards for organic livestock and livestock products (Council Regulations EC 1804/1999 amending Directive EEC 2092/91). However, according to these rules, Treatment $\mathrm{B}$ lacked access to roughage. This design was made in order to be able to make a reasonable comparison of Treatment B with the conventionally treated pigs A, which had no access to roughage and outdoor area. In the three treatments fed organic concentrate, the pigs in the first 3 trials in the period 1999-2000 were fed a concentrate mixture based on $28 \%$ barley/pea, $31.7 \%$ wheat, $16 \%$ oat, $22 \%$ GMO-free soybean meal, $0.2 \%$ solivit-micro minerals- 106 , $0.3 \%$ salt, $1.1 \%$ limestone and $0.7 \%$ dicalcium phosphate. In the last trial taking place in the autumn 2000 and the winter 2001 , the composition was $8.7 \%$ barley, $28 \%$ barley/pea, $20 \%$ wheat, $20 \%$ oat, $21 \%$ GMO-free soybean meal, $0.2 \%$ solivit-micro minerals- $106,0.3 \%$ salt, $1.1 \%$ limestone and $0.7 \%$ dicalcium phosphate given in an indoor feeding trough twice a day. In the control treatment with $100 \%$ conventional concentrate, the pigs were fed a standard concentrate mixture from DIAS Research Centre Foulum mainly based on $50 \%$ barley, $24 \%$ soybean meal, $20 \%$ wheat, $0.3 \%$ lysine mixture, $0.1 \%$ methionine mixture, $2 \%$ soy oil and $1 \%$ molasses plus minerals and vitamins. Only pigs from this treatment had no access to an outdoor area. Average results from the feed analyses of protein, fat, crude fibre, ash, EDOM, digestible energy and net energy from all four trials are shown in Table 3. Average results from the feed analyses of fatty acids, retinol, $\beta$-carotene and $\alpha$-tocopherol in conventional and organic concentrate and organic roughage of clover grass silage and barley/pea silage are shown in Table 4.

\subsection{Slaughtering procedure, sampling and analysis}

Divided over two slaughter days, the 40 pigs in each of the four trials were transported to the DIAS experimental slaughter plant at Research Centre Foulum when the average weight was around $108 \mathrm{~kg}$ live weight. Twenty pigs were

Table 2

Number of pigs per trial and treatment distributed to the two slaughter days per trial

\begin{tabular}{|c|c|c|c|c|}
\hline \multirow[t]{2}{*}{ Treatment } & A & $\mathrm{B}$ & $\mathrm{C}$ & $\mathrm{D}$ \\
\hline & No. of pigs & No. of pigs & No. of pigs & No. of pigs \\
\hline \multicolumn{5}{|l|}{ Trial 1 Summer } \\
\hline Second slaughter day, 12th October & 2 & 2 & 8 & 7 \\
\hline \multicolumn{5}{|l|}{ Trial 2 Summer } \\
\hline First slaughter day, 25th January & 8 & 8 & 2 & 2 \\
\hline First slaughter day, 5th September & 9 & 7 & 2 & 1 \\
\hline Second slaughter day, 19th September & 1 & 2 & 8 & 9 \\
\hline \multicolumn{5}{|l|}{ Trial 4 Winter } \\
\hline First slaughter day, 9th January & 8 & 7 & 2 & 2 \\
\hline Second slaughter day, 30th January & 1 & 1 & 6 & 7 \\
\hline
\end{tabular}

\footnotetext{
${ }^{a}$ One pig carcass cancelled during the slaughter process.
} 
Table 3

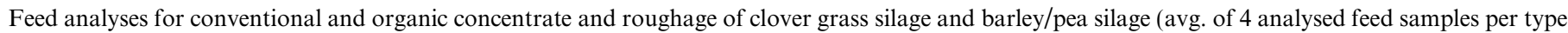
of concentrate and type of roughage, one sample from each of the 4 trials)

\begin{tabular}{|c|c|c|c|c|}
\hline \multirow[t]{2}{*}{ Treatment } & \multicolumn{2}{|l|}{ Concentrate } & \multicolumn{2}{|l|}{ Roughage } \\
\hline & A Conv. conc. & $\mathrm{B}+\mathrm{C}+\mathrm{D}$ Org. conc. & C Barley/pea silage & D Clover grass sil. \\
\hline Total $N$ (Kjeldahl) $(\mathrm{g} / 100 \mathrm{~g})$ & 3.33 & 3.35 & 2.29 & 2.92 \\
\hline Stoldt fat (g/100 g) & 5.47 & 3.57 & 3.54 & 4.53 \\
\hline Crude fibre $(\mathrm{g} / 100 \mathrm{~g})$ & 4.65 & 5.89 & 28.31 & 24.39 \\
\hline $\operatorname{Ash}(g / 100 \mathrm{~g})$ & 6.01 & 5.46 & 8.99 & 9.92 \\
\hline EDOM $^{\mathrm{a}}$ (pig) (g/100 g org. matter) & 88.6 & 87.0 & 52.0 & 60.9 \\
\hline Gross energy & 18.9 & 18.6 & 17.6 & 17.9 \\
\hline Digestible energy & 15.88 & 15.28 & 7.63 & 9.53 \\
\hline Metabolisable energy & 15.3 & 14.73 & 7.23 & 9.03 \\
\hline Net energy $\left(\mathrm{MJ}^{\mathrm{b}} / \mathrm{kg} \mathrm{DM}^{\mathrm{c}}\right)$ & 9.6 & 9.16 & 3.55 & 4.89 \\
\hline Dry matter (\%) & 89.4 & 89.6 & & \\
\hline Freeze-dried dry matter $(\%)$ & & & 92.1 & 89.5 \\
\hline Net energy (MJ/kg feed) & 8.57 & 8.20 & 0.87 & 2.01 \\
\hline
\end{tabular}

${ }^{a}$ Enzyme-digestible organic matter.

b Feed units - pigs; 1 FUp $=7.72 \mathrm{MJ}$.

c Dry matter.

Table 4

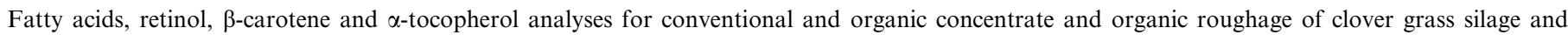
barley/pea silage

\begin{tabular}{|c|c|c|c|c|c|}
\hline \multirow[t]{2}{*}{ Result } & \multirow{2}{*}{$\begin{array}{l}\text { Dry matter } \\
\text { Unit }\end{array}$} & \multicolumn{2}{|c|}{ Concentrate } & \multicolumn{2}{|c|}{ Roughage silage } \\
\hline & & Organic & Conventional & Barley/pea & Clover grass \\
\hline Retinol IU/kg DM & & 3350 & 2300 & & \\
\hline$\beta$-Carotene mg/kg & & & & 18 & 50 \\
\hline \multirow[t]{2}{*}{$\alpha$-Tocopherol mg/kg DM } & & 56 & 65 & 28 & 41 \\
\hline & & Digest. \% & Digest. $\%$ & Digest. $\%$ & Digest. $\%$ \\
\hline C14:0-myristic acid & $\mathrm{g} / 100 \mathrm{~g} \mathrm{FA}$ & 0.2 & 1.0 & 2.0 & 0.7 \\
\hline C16:0-palmitic acid & $\mathrm{g} / 100 \mathrm{~g} \mathrm{FA}$ & 19.2 & 23.4 & 22.9 & 16.7 \\
\hline C16:1-palmitol acid & $\mathrm{g} / 100 \mathrm{~g} \mathrm{FA}$ & 0.3 & 1.3 & 0.9 & 0.0 \\
\hline C18:0-stearic acid & $\mathrm{g} / 100 \mathrm{~g} \mathrm{FA}$ & 2.0 & 8.0 & 3.2 & 2.2 \\
\hline C18:1-oleic acid & $\mathrm{g} / 100 \mathrm{~g} \mathrm{FA}$ & 21.6 & 25.7 & 8.7 & 2.3 \\
\hline C18:2-linolic acid & $\mathrm{g} / 100 \mathrm{~g} \mathrm{FA}$ & 48.6 & 34.1 & 28.7 & 16.9 \\
\hline C18:3W3-linolenic acid & $\mathrm{g} / 100 \mathrm{~g} \mathrm{FA}$ & 5.5 & 3.6 & 26.6 & 57.8 \\
\hline C20:0-arachic acid & $\mathrm{g} / 100 \mathrm{~g} \mathrm{FA}$ & 0.3 & 0.3 & 0.6 & 0.6 \\
\hline C22:0-behenic acid & g/100 g FA & 0.3 & 0.3 & 1.3 & 1.1 \\
\hline Sum fatty acids, $\mathrm{g} / 100 \mathrm{~g}$ feed & & 2.73 & 4.14 & 1.44 & 2.36 \\
\hline Total fatty acids, g/100 g fat & & 80.2 & 82.3 & 39.3 & 49.7 \\
\hline
\end{tabular}

slaughtered per slaughter day. In the two summer trials there were 14 days between the two slaughter days, while there were three weeks between the two slaughter days in the two winter trials (Table 2). All pigs were weighed and ham-tattooed with the ear-number on the morning before slaughter, and they arrived to the slaughter plant after $1.5 \mathrm{~h}$ of transport from Rugballegaard. At weighing, the pigs were marked with different colours according to treatment. Due to the different growth rates of Treatments A and $\mathrm{B}$ on one hand and Treatments $\mathrm{C}$ and $\mathrm{D}$ on the other, around $80 \%$ of the pigs of Treatments $\mathrm{A}$ and $\mathrm{B}$ and $20 \%$ of Treatments $\mathrm{C}$ and $\mathrm{D}$ were delivered at the first slaughter day and vice versa the second slaughter day (Table 2). The average live weight at slaughter of the whole experiment was $108.5 \pm 6.8 \mathrm{~kg}$ SD without statistical corrections.

On each slaughter day the pigs of the four treatments were kept in separate compartments during transport to the abattoir where the pigs arrived at $8.00 \mathrm{a} . \mathrm{m}$. in a vehicle authorised for transport of pigs. The A and B treatments were mixed in one pen at the abattoir and Treatments $C$ and $\mathrm{D}$ in another pen. At the first slaughter day, the pigs of Treatments A and B were slaughtered alternately with an interval of $10 \mathrm{~min}$ starting on arrival to the abattoir and thereafter alternately Treatment $\mathrm{C}$ and $\mathrm{D}$ pigs. At the second slaughter day the pigs of Treatments C and D were alternately slaughtered with an interval of $10 \mathrm{~min}$ just after arrival to the abattoir and thereafter alternately Treatment $\mathrm{A}$ and $\mathrm{B}$ pigs.

The pigs were stunned with $80 \% \mathrm{CO}_{2}$ for three min, exsanguinated, scalded at $62{ }^{\circ} \mathrm{C}$ for three min, cleaned, and eviscerated within $30 \mathrm{~min}$. After $45 \mathrm{~min}$ the carcasses were placed at $4{ }^{\circ} \mathrm{C}$ in a chilling room.

Carcass meat percentages were determined with a FatO-Meat'er (SFK-Technologies, Denmark). 
Meat quality traits were investigated on LD from the pigs. Duplicate $\mathrm{pH}$ measurements were made in LD $24 \mathrm{~h}$ post-mortem with an insertion glass electrode (Radiometer, Lyon, France) connected to a $\mathrm{pH}$-meter (Metrohm Model 704, Herisau, Switzerland). The electrode was calibrated at $4{ }^{\circ} \mathrm{C}$ in buffers with pH 4.01 and 7.00 (Radiometer, Lyon, France).

LD samples $(5 \mathrm{~cm})$ taken at the last rib $24 \mathrm{~h}$ postmortem were used for both the following colour measurements and all the other subsequent assays. Meat colour of bloomed $\left(1 \mathrm{~h}\right.$ at $\left.14^{\circ} \mathrm{C}\right)$ samples was measured using a Minolta Chroma Meter CR-300 (Osaka, Japan), with a $D_{65}$ light source calibrated against a white tile $\left(L^{*}=92.30, a^{*}=.32\right.$, and $b^{*}=.33$ ). Pigment (myoglobin units) was determined in accordance with the method described by Oksbjerg et al. (2000). Pigment (haematin) was determined in accordance with the method described by Hornsey (1956). Drip loss was measured according to a reference method described by Honikel (1996). Tocopherols (vitamin E) in loin muscle and liver as well as vitamin A in liver were analysed according to Jensen et al. (1998). Lipid oxidation was measured as formation of thiobarbituric acid reactive substances (TBARS) according to Tarladgis, Pearson, and Dugan (1964) with modifications of Jensen et al. (1998). Samples of backfat measuring $5 \times 10 \mathrm{~cm}$ were vacuum-packed and frozen $\left(-20^{\circ} \mathrm{C}\right)$ until analysis for fatty acids by GC-FID: $20-25 \mathrm{~g}$ of backfat were cut in smaller pieces and melted in a microwave oven for $3 \mathrm{~min}$ at $450 \mathrm{~W}$, and lipid was extracted as described by Bligh and Dyer (1959). Fatty acids were esterified with methanol in $\mathrm{NaOH}$ catalysed by borontrifluride $\left(\mathrm{BF}_{3}-\right.$ $\mathrm{MeOH})$. The methylesters were analysed by gas chromatography with a flame ionisation detector (GC-FID, carrier gas helium HP 6890) on a CP-sil 88 column (50 m, ID $0.25 \mathrm{~mm}$, film $0.20 \mu \mathrm{m}$ Chrompack). The temperature program was: $70^{\circ} \mathrm{C}$ for $2 \mathrm{~min}, 30^{\circ} / \mathrm{min}$ until $120^{\circ} \mathrm{C}, 2^{\circ} / \mathrm{min}$ until $180^{\circ} \mathrm{C}, 180^{\circ} \mathrm{C}$ for $5 \mathrm{~min}, 20^{\circ} / \mathrm{min}$ until $240^{\circ} \mathrm{C}$ and finally $240{ }^{\circ} \mathrm{C}$ for $10 \mathrm{~min}$. Injector and FID-detector: $300{ }^{\circ} \mathrm{C}$. Column flow: $0.8 \mathrm{ml}$ carrier gas $/ \mathrm{min}$. The methyl esters were identified by comparing retention times of FAME standards (Swine). Sensory profiling by a trained sensory panel ( 8 assessors) was performed on $20 \mathrm{~mm}$ slices of the LD with approx. $2 \mathrm{~mm}$ fat. The slices were fried without additional fat or oil on a hot plate to a core temperature of $65^{\circ} \mathrm{C}$. Only the centre of the slices was used in the profiling. During training the panel decided to use 12 sensory attributes: Meat odour, pig odour, acidic odour, brown surface, meat flavour, pig flavour, acidic flavour, sweet flavour, hardness, juiciness, tenderness and chewing time. The intensity of each attribute was assessed on an unstructured scale where data subsequently were transformed to a numeric scale from 0 to 15 . One side of each carcass was cut into parts, and fore-end, loin, belly and leg were weighed. The following fresh products were produced according to ESS-FOOD (2005) and weighed: Loin without rind and bone (cut 1669), belly without rind and bone (cut 1828), leg round cut (cut 1203), leg muscles with- out rind, bone and fat (cut 1223) and trimmed tenderloin (cut 1905) (both pieces). Fat thickness of loin and leg, circumference of loin and length of loin and belly were measured.

\subsection{Statistical analysis}

In general data were analysed using the Mixed Models Procedure of Statistical Analysis Systems Institute (SAS Inst. Inc., Cary, NC), by means of models including the fixed effects of treatment, sex, season and interactions between the fixed effects. Replicate within treatment $*$ season and litter of the pigs within season were used as random effects.

Most of the statistical Y-differences were found between the seasons (summer and winter). Therefore most of the statistical analysis included season instead of trial number in the model as well as interaction between treatment and season. However, when a significant effect of trial number was noticed opposite to no statistical significance of season, the trial number substituted season in the Mixed Models Procedure of Statistical Analysis Systems Institute (SAS Inst. Inc., Cary, NC).

In the case of TBARS only a GLM Procedure of Statistical Analysis Systems Institute (SAS Inst. Inc., Cary, NC) was used, by means of models including the fixed effects of treatment, sex, time, season and interactions between the fixed effects.

\section{Results}

\subsection{Production results}

Production results are shown in Table 5. Live weight and warm carcass weight at slaughter were significantly higher in Treatments A and B compared with Treatments $\mathrm{C}$ and D $(P<0.001)$. Consequently, in a subsequent analysis of covariance, warm carcass weight was included as covariate to adjust daily gain and percentage of lean meat.

A minor, but significant, decrease was found in daily gain of Treatment B compared with Treatment A $(P<0.05)$, while no or only a slight difference in production, carcass and meat quality results was seen between the conventional control Treatment $\mathrm{A}$ and the organic control Treatment $\mathrm{B}$. In contrast, Treatments $\mathrm{C}$ and $\mathrm{D}$ reduced daily gain of the pigs significantly compared with both Treatments A and B $(P<0.001)$. Moreover, the results showed that Treatments $\mathrm{C}$ and $\mathrm{D}$ resulted in a more pronounced decrease in daily gain during winter time vs. summer time compared with Treatments $\mathrm{A}$ and $\mathrm{B}$ due to a significant interaction between treatments and seasons $(P<0.05)$. It was noticed that in the two restricted treatments, the castrated male pigs decreased their daily gain more than the female pigs, as reflected in the interaction between sex and treatment $(P<0.05)$ (Table 5). The feed conversion ratio was superior during summer time $(P<0.001)$, but did not differ significantly between the four 
Table 5

Production results

\begin{tabular}{|c|c|c|c|c|c|}
\hline Treatment & A & B & $\mathrm{C}$ & $\mathrm{D}$ & $\begin{array}{l}\text { Significance of } \\
\text { treatment } P\end{array}$ \\
\hline Concentrate type & Conventional & Organic $^{\mathrm{A}}$ & Organic & Organic & \\
\hline Percent of concentrate & 100 & 100 & 70 & 70 & \\
\hline Initial weight & $40.5 \pm 0.8$ & $40.3 \pm 0.8$ & $40.5 \pm 0.8$ & $40.5 \pm 0.8$ & NS \\
\hline Experimental days & $76.5^{\mathrm{a}}$ & $76.9^{\mathrm{a}}$ & $87.5^{\mathrm{b}}$ & $87.1^{\mathrm{b}}$ & $<0.001$ \\
\hline Live weight at slaughter & $114.8 \pm 1.1^{\mathrm{a}}$ & $111.1 \pm 1.1^{\mathrm{b}}$ & $102.9 \pm 1.1^{\mathrm{c}}$ & $103.7 \pm 1.1^{\mathrm{c}}$ & $<0.001$ \\
\hline Warm carcass weight & $89.6 \pm 0.9^{\mathrm{a}}$ & $86.0 \pm 0.9^{\mathrm{b}}$ & $79.5 \pm 0.9^{c}$ & $80.3 \pm 0.9^{c}$ & $<0.001$ \\
\hline Daily gain, g & $999 \pm 14^{\mathrm{a}}$ & $935 \pm 14^{\mathrm{b}}$ & $726 \pm 14^{\mathrm{c}}$ & $731 \pm 14^{\mathrm{c}}$ & $<0.001$ \\
\hline Daily gain, g (summer) & $1008^{\mathrm{a}} \pm 19$ & $936^{\mathrm{bc}} \pm 19$ & $784^{\mathrm{d}} \pm 19$ & $771^{\mathrm{d}} \pm 19$ & $*$ \\
\hline Daily gain, g (winter) & $988^{\mathrm{ab}} \pm 20$ & $954^{\mathrm{c}} \pm 20$ & $662^{\mathrm{e}} \pm 20$ & $689^{\mathrm{e}} \pm 20$ & \\
\hline Daily gain, g (castrates) & $1014^{\mathrm{a}} \pm 19$ & $954^{\mathrm{bc}} \pm 19$ & $704^{\mathrm{d}} \pm 18$ & $722^{\mathrm{d}} \pm 18$ & $* *$ \\
\hline Daily gain, g (gilts) & $984^{\mathrm{ab}} \pm 18$ & $915^{\mathrm{c}} \pm 18$ & $748^{\mathrm{e}} \pm 18$ & $740^{\mathrm{e}} \pm 18$ & \\
\hline MJ per kg gain & $23.1 \pm 0.5$ & $23.9 \pm 0.5$ & $22.9 \pm 0.5$ & $22.7 \pm 0.5$ & NS \\
\hline MJ per kg gain, summer & $22.1 \pm 0.7$ & $23.7 \pm 0.7$ & $21.0 \pm 0.7$ & $20.7 \pm 0.7$ & $* * *$ \\
\hline MJ per kg gain, winter & $24.1 \pm 0.7$ & $24.4 \pm 0.7$ & $25.1 \pm 0.8$ & $24.6 \pm 0.7$ & \\
\hline MJ per pen totally & $8392 \pm 255$ & $8230 \pm 270$ & $7172 \pm 270$ & $7010 \pm 255$ & $<0.001$ \\
\hline $\mathrm{MJ}$ in roughage per pen & - & - & $257.8 \pm 116$ & $602.9 \pm 108$ & $<0.001$ \\
\hline
\end{tabular}

a-e Least square means and S.E.M. within rows not sharing a common superscript letter differ significantly.

A Organic treatment, but without roughage.

* Interaction between treatment and season $P<0.05$.

** Interaction between treatment and sex $P<0.05$.

*** Season $P<0.001$

treatments (Table 5). The amount of roughage, either as barley/pea silage Treatment $\mathrm{C}$ or clover grass silage Treatment $\mathrm{D}$, was consumed in amounts of $3.8 \%$ and $8.2 \%$ of total energy intake, when concentrate was fed at a restricted level $(70 \%)$. This clearly shows that pigs on Treatment $\mathrm{D}$ on an energy basis ate significantly more roughage compared with pigs on Treatment $\mathrm{C}(P<$ 0.001) (Table 5).

\subsection{Carcass and meat quality}

Carcass and meat quality characteristics are seen in Tables 6-9. As a consequence of treatment, the percentage of lean meat in Treatments A and B is smaller than Treatments $\mathrm{C}$ and $\mathrm{D}$ (Table 6). Female pigs had a higher percentage of lean meat compared with castrated male pigs $(P<0.001)$, and their lean meat percentage was highest in the winter season $(P<0.01)$.

Intramuscular fat (IMF) constituted $1.2 \%$ in loin from Treatments $\mathrm{C}$ and D compared with 1.6 and $1.5 \%$, respectively, in Treatments A and B. There was a significant sex difference as the female pigs had $1.3 \%$ IMF, and the castrated male pigs had $1.5 \%(P<0.05)$.

The technological meat quality of $M$. longissimus dorsi did not differ with regard to ultimate $\mathrm{pH}$, pigment (myoglobin units and haematin) content and drip loss (Table 6).

Table 6

Carcass and meat quality

\begin{tabular}{|c|c|c|c|c|c|}
\hline Treatment & A & B & $\mathrm{C}$ & $\mathrm{D}$ & Significance of treatment $P$ \\
\hline Concentrate type & Conventional & Organic $^{\mathrm{A}}$ & Organic & Organic & \\
\hline Percent of concentrate & 100 & 100 & 70 & 70 & \\
\hline Meat percentage (Fat-O-Meter) & $60.6 \pm 0.2^{\mathrm{a}}$ & $60.4 \pm 0.2^{\mathrm{a}}$ & $61.3 \pm 0.2^{\mathrm{b}}$ & $61.8 \pm 0.2^{\mathrm{b}}$ & $<0.001$ \\
\hline Meat percentage (winter) & $61.5 \pm 0.4$ & $61.2 \pm 0.4$ & $61.5 \pm 0.4$ & $61.9 \pm 0.4$ & \\
\hline Meat percentage (female pigs) & $61.0 \pm 0.3$ & $61.0 \pm 0.3$ & $61.8 \pm 0.3$ & $62.3 \pm 0.3$ & ** \\
\hline Meat percentage (castrates) & $60.3 \pm 0.3$ & $59.9 \pm 0.3$ & $60.8 \pm 0.3$ & $61.2 \pm 0.3$ & \\
\hline Pigment, myoglobin units $\mathrm{mg} / \mathrm{g}$ & $0.78 \pm 0.03$ & $0.76 \pm 0.03$ & $0.82 \pm 0.03$ & $0.78 \pm 0.03$ & NS \\
\hline Pigment, haematin $\mathrm{mg} / \mathrm{kg}$ & $26.5 \pm 0.6$ & $25.9 \pm 0.6$ & $26.3 \pm 0.6$ & $25.2 \pm 0,6$ & NS \\
\hline Drip loss $\%$ & $6.03 \pm 0.34$ & $6.52 \pm 0.34$ & $6.53 \pm 0.34$ & $6.25 \pm 0.34$ & NS \\
\hline Drip loss $\%$, summer & $5.87 \pm 0.48$ & $6.05 \pm 0.48$ & $5.97 \pm 0.47$ & $5.77 \pm 0.48$ & \\
\hline Drip loss $\%$, winter & $6.18 \pm 0.49$ & $7.15 \pm 0.50$ & $7.22 \pm 0.50$ & $6.75 \pm 0.49$ & \\
\hline
\end{tabular}

a,b Least square means and S.E.M. within rows not sharing a common superscript letter differ significantly.

A Organic treatment, but without roughage.

* Season $P<0.01$.

** Sex $P<0.001$.

${ }^{* * *}$ Season $P<0.05$. 
Table 7

Meat quality

\begin{tabular}{|c|c|c|c|c|c|}
\hline Treatment & A & $\mathrm{B}$ & $\mathrm{C}$ & $\mathrm{D}$ & $\begin{array}{l}\text { Significance of } \\
\text { treatment } P\end{array}$ \\
\hline Concentrate type & Conventional & Organic $^{\mathrm{A}}$ & Organic & Organic & \\
\hline Percent of concentrate & 100 & 100 & 70 & 70 & \\
\hline Roughage type (ad lib.) & None & None & Barley/pea sil. & Clover gr. sil. & \\
\hline TBARS mg MDA eq. per kg & $7.93 \times 10-8 \mathrm{a}$ & $8.30 \times 10^{-8 a}$ & $9.38 \times 10^{-8 b}$ & $10.00 \times 10-8 b$ & $<0.001$ \\
\hline Alfa-tocopherol in muscle, $\mu \mathrm{g} / \mathrm{g}$ & $3.13 \pm 0.11^{\mathrm{a}}$ & $3.15 \pm 0.11^{\mathrm{a}}$ & $2.98 \pm 0.11^{\mathrm{ab}}$ & $2.64 \pm 0.11^{\mathrm{b}}$ & $<0.05$ \\
\hline Alfa-tocopherol in liver, $\mu \mathrm{g} / \mathrm{g}$ & $6.83 \pm 0.29$ & $6.93 \pm 0.30$ & $6.99 \pm 0.30$ & $5.92 \pm 0.30$ & $<0.10$ \\
\hline Retinol in liver, $\mu \mathrm{g} / \mathrm{g}$ & $82.0 \pm 2.9$ & $69.1 \pm 2.9$ & $72.6 \pm 2.9$ & $75.5 \pm 2.9$ & $<0.05$ \\
\hline
\end{tabular}

a,b Least square means and S.E.M. within rows not sharing a common superscript letter differ significantly.

A Organic treatment, but without roughage.

However, pigment (myoglobin units) content and drip loss showed differences between seasons as pork from the summer pigs had less pigment $(P<0.05)$ and drip loss $(P<0.05)$.

The TBARS (mg MDA eq. per $\mathrm{kg}$ ) was found to be higher in pork from roughage-fed pigs from Treatments $\mathrm{C}$ and D compared with both Treatment A and B (Table $7)$, with a significant difference between seasons $(P<$ $0.001)$, an interaction between treatment and season $(P<$ $0.05)$ and an interaction between sex $*$ season $(P<0.001)$ (Table 8).

The vitamin $\mathrm{E}$ content in muscle and liver was lowest in pigs from Treatment $\mathrm{D}(P<0.05 ; P<0.10)$ compared with the other treatments (Table 7). However, the vitamin E content differed between the trials $(P<0.001)$ with a ten-

Table 8

TBARS interaction between sex and season

\begin{tabular}{llll}
\hline Sex & Castrated male pigs & Female pigs & Interaction sex $*$ season $P$ \\
\hline Summer & $8.55 \times 10^{-8}$ & $9.30 \times 10^{-8}$ & $<0.001$ \\
Winter & $10.10 \times 10^{-8}$ & $8.11 \times 10^{-8}$ & \\
\hline
\end{tabular}

dency to interaction between trial $*$ treatment $(P<0.10)$ (data not shown). The vitamin A content in liver was higher in Treatment A $(P<0.05)$ (Table 7), however, it differed dependent on season $(P<0.001)$ with an interaction between treatment*season $(P<0.01)$ (data not shown).

\subsection{Fatty acid composition in backfat}

The contents of saturated, monounsaturated, polyunsaturated fatty acids and the iodine value are shown in Table 9. Treatments $\mathrm{C}$ and $\mathrm{D}$ had a lower content of saturated fatty acids $(2 \%)$ compared with Treatments $\mathrm{A}$ and $\mathrm{B}$. The relationship between the contents of monounsaturated fatty acids was Treatment A $>$ Treatment $\mathrm{B}>$ Treatments $\mathrm{C}$ and D (Table 9), whereas the relationship for contents of polyunsaturated fatty acids was Treatments D and C $>$ Treatment B $>$ Treatment A (Table 9). Accordingly the iodine value increased from 68.3 in Treatment $\mathrm{A}$ to 70.2 in Treatment B, further to 74.1 in Treatment $\mathrm{C}$ and 75.1 in Treatment D (Table 9).

The results showed no difference between the four treatments in Minolta colour values $L^{*}$-value (lightness),

Table 9

Fatty acid composition in backfat and Minolta meat colour characteristics

\begin{tabular}{|c|c|c|c|c|c|}
\hline Treatment & A & $\mathrm{B}$ & $\mathrm{C}$ & $\mathrm{D}$ & Effect of treatment $P$ \\
\hline Concentrate type & Conventional & Organic & Organic & Organic & \\
\hline Percent of concentrate & $100 \%$ & $100 \%$ & $70 \%$ & $70 \%$ & \\
\hline \multicolumn{6}{|l|}{ Fatty acids } \\
\hline Saturated fatty acids (\%) & $40.7^{\mathrm{a}} \pm 0.4$ & $40.4^{\mathrm{a}} \pm 0.4$ & $38.6^{\mathrm{b}} \pm 0.4$ & $38.5^{\mathrm{b}} \pm 0.4$ & $<0.05$ \\
\hline Monounsaturated fatty acids (\%) & $45.3^{\mathrm{a}} \pm 0.3$ & $43.3^{b} \pm 0.3$ & $42.5^{\mathrm{c}} \pm 0.3$ & $41.9^{\mathrm{c}} \pm 0.3$ & $<0.05$ \\
\hline Polyunsaturated fatty acids (\%) & $13.6^{\mathrm{a}} \pm 0.3$ & $15.4^{\mathrm{b}} \pm 0.3$ & $17.5^{\mathrm{c}} \pm 0.3$ & $18.0^{\mathrm{c}} \pm 0.3$ & $<0.05$ \\
\hline Iodine value & $68.3^{\mathrm{a}} \pm 0.6$ & $70.2^{\mathrm{b}} \pm 0.6$ & $74.1^{\mathrm{c}} \pm 0.6$ & $75.1^{\mathrm{c}} \pm 0.6$ & $<0.05$ \\
\hline $\mathrm{C} 16: 0$ & $25.0^{\mathrm{a}}$ & $24.8^{\mathrm{a}}$ & $23.9^{\mathrm{b}}$ & $23.4^{\mathrm{b}}$ & $<0.05$ \\
\hline $\mathrm{C} 16: 1$ & $2.5^{\mathrm{a}}$ & $2.3^{\mathrm{b}}$ & $2.6^{\mathrm{a}}$ & $2.4^{\mathrm{ab}}$ & $<0.05$ \\
\hline $\mathrm{C} 17: 0$ & $0.4^{\mathrm{a}}$ & $0.3^{\mathrm{ab}}$ & $0.3^{\mathrm{ab}}$ & $0.3^{\mathrm{b}}$ & $<0.05$ \\
\hline C18:0 & $13.5^{\mathrm{ab}}$ & $13.7^{\mathrm{a}}$ & $12.9^{\mathrm{b}}$ & $13.1^{\mathrm{ab}}$ & $<0.05$ \\
\hline C18:1 & $41.9^{\mathrm{a}}$ & $40.3^{\mathrm{b}}$ & $39.5^{\mathrm{bc}}$ & $39.1^{\mathrm{c}}$ & $<0.05$ \\
\hline C18:2 & $10.7^{\mathrm{a}}$ & $12.3^{\mathrm{b}}$ & $14.1^{\mathrm{c}}$ & $14.1^{\mathrm{c}}$ & $<0.05$ \\
\hline C18:3 & $2.0^{\mathrm{a}}$ & $2.0^{\mathrm{a}}$ & $2,2^{\mathrm{a}}$ & $2.7^{\mathrm{b}}$ & $<0.05$ \\
\hline \multicolumn{6}{|l|}{ Meat colour } \\
\hline$L^{*}$-value & $51.7 \pm 0.4$ & $51.9 \pm 0.4$ & $51.7 \pm 0.4$ & $51.8 \pm 0.4$ & NS \\
\hline$a^{*}$-value & $6.6 \pm 0.2$ & $6.5 \pm 0.2$ & $6.4 \pm 0.2$ & $6.0 \pm 0.2$ & NS \\
\hline$b^{*}$-value & $4.9 \pm 0.15$ & $4.9 \pm 0.15$ & $4.8 \pm 0.15$ & $4.7 \pm 0.15$ & NS \\
\hline
\end{tabular}

${ }^{\mathrm{a}-\mathrm{c}}$ Experimental treatments for the measured characteristics not sharing a common superscript letter within rows differ significantly. 
Table 10

Sensory attribute score in pork from the different management systems of $20 \mathrm{~mm}$ slices of $M$. longissimus dorsi fried to a core temperature of $65^{\circ} \mathrm{C}$

\begin{tabular}{|c|c|c|c|c|c|}
\hline Treatment & A & $\mathrm{B}$ & $\mathrm{C}$ & $\mathrm{D}$ & Effect of treatment $P$ \\
\hline Concentrate type & Conventional & Organic & Organic & Organic & \\
\hline Percent of concentrate & $100 \%$ & $100 \%$ & $70 \%$ & $70 \%$ & \\
\hline Meat odour & $8.0 \pm 0.1$ & $7.9 \pm 0.1$ & $7.8 \pm 0.1$ & $7.8 \pm 0.1$ & NS \\
\hline Piggy odour & $1.4 \pm 0.1$ & $1.4 \pm 0.1$ & $1.6 \pm 0.1$ & $1.6 \pm 0.1$ & NS \\
\hline Acidic odour & $2.0^{\mathrm{a}} \pm 0.1$ & $2.1^{\mathrm{ab}} \pm 0.1$ & $2.1^{\mathrm{ab}} \pm 0.1$ & $2.3^{\mathrm{b}} \pm 0.1$ & $<0.05$ \\
\hline \multicolumn{6}{|l|}{ Brown surface } \\
\hline Summer & $6.2^{\mathrm{a}} \pm 0.3$ & $7.2^{b} \pm 0.3$ & $7.1^{\mathrm{b}} \pm 0.3$ & $6.7^{\mathrm{b}} \pm 0.3$ & $<0.01$ \\
\hline Winter & $7.5^{\mathrm{a}} \pm 0.3$ & $6.5^{\mathrm{b}} \pm 0.3$ & $7.2^{\mathrm{ab}} \pm 0.3$ & $7.9^{\mathrm{a}} \pm 0.3$ & \\
\hline Meat flavour & $8.0^{\mathrm{ab}} \pm 0.1$ & $8.1^{\mathrm{a}} \pm 0.1$ & $7.8^{\mathrm{bc}} \pm 0.1$ & $7.6^{\mathrm{c}} \pm 0.1$ & $<0.01$ \\
\hline Piggy flavour & $2.8 \pm 0.1$ & $2.8 \pm 0.1$ & $2.9 \pm 0.1$ & $3.0 \pm 0.1$ & NS \\
\hline Acidic flavour & $3.0 \pm 0.1$ & $3.0 \pm 0.1$ & $3.2 \pm 0.1$ & $3.2 \pm 0.1$ & NS \\
\hline Sweet flavour & $0.4 \pm 0.1$ & $0.5 \pm 0.1$ & $0.5 \pm 0.1$ & $0.4 \pm 0.1$ & NS \\
\hline Hardness & $6.0^{\mathrm{a}} \pm 0.2$ & $6.0^{\mathrm{a}} \pm 0.2$ & $6.9^{\mathrm{b}} \pm 0.2$ & $6.9^{\mathrm{b}} \pm 0.2$ & $<0.0001$ \\
\hline Juiciness & $8.9 \pm 0.1$ & $8.8 \pm 0.1$ & $8.7 \pm 0.1$ & $8.8 \pm 0.1$ & NS \\
\hline Tenderness & $8.7^{\mathrm{a}} \pm 0.2$ & $8.6^{\mathrm{a}} \pm 0.2$ & $7.5^{\mathrm{b}} \pm 0.2$ & $7.5^{\mathrm{b}} \pm 0.2$ & $<0.0001$ \\
\hline Chewing time & & & & & $<0.05$ \\
\hline Summer & $9.2^{\mathrm{ac}} \pm 0.3$ & $8.6^{\mathrm{a}} \pm 0.3$ & $10.1^{\mathrm{b}} \pm 0.3$ & $9.6^{\mathrm{bc}} \pm 0.3$ & \\
\hline Winter & $8.6^{\mathrm{a}} \pm 0.3$ & $8.9^{\mathrm{a}} \pm 0.3$ & $9.4^{\mathrm{b}} \pm 0.3$ & $10.1^{b} \pm 0.3$ & \\
\hline
\end{tabular}

Intensity scale $0-15$.

${ }^{\mathrm{a}-\mathrm{c}}$ Experimental treatments for the measured characteristics not sharing a common superscript letter within rows differ significantly.

$a^{*}$-value (redness) and $b^{*}$-value (yellowness) (Table 9). However, a seasonal effect was found as the $a^{*}$ - and $b_{*}$-values were significantly higher in the winter season (for $a^{*}$ summer was 5.9 and winter was 6.9 , and for $b^{*}$ summer was 4.3 and winter was 5.4).

\subsection{Sensory profile of loin slices}

Treatment A resulted in less acidic odour than Treatment B. Treatment B resulted in more meat flavour than Treatments $\mathrm{C}$ and $\mathrm{D}$, and Treatment $\mathrm{A}$ had more meat flavour than Treatment D (Table 10). There were no differences for the rest of the odour and flavour attributes. For the texture attributes, Treatments $\mathrm{C}$ and $\mathrm{D}$ gave rise to less tender, more hard meat, which needed longer chewing time than Treatments A and B. For chewing time though, there was interaction with season $(P<0,05)$ as Treatments $\mathrm{A}$ and $\mathrm{D}$ were not significantly different in summer. Finally, an interaction between fried meat colour and season (P 0.01) was registered where meat in the summer from Treatment A was lighter than the other treatments, and meat in the winter from Treatment B was lighter (Table 10).

\subsection{Yield and dimensions of cuts and products}

In Table 11, the yield of the fore-end and loin cuts did not differ significantly between treatments. The belly cut was approx. $300 \mathrm{~g}$ heavier for Treatments A and B than for Treatments $\mathrm{C}$ and $\mathrm{D}$. The leg cut was approx. $200 \mathrm{~g}$ lighter for Treatment A than for Treatments C and D - TreatmentB being intermediate and not significantly different from the other treatments. For the products, Treatments A and B had lighter loins and heavier bellies than Treatments $\mathrm{C}$ and $\mathrm{D}$. The round cut leg was lighter for Treatment A than for Treatments C and $\mathrm{D}$, and Treatments $\mathrm{C}$ and $\mathrm{D}$ had heavier leg muscles than Treatment B, which had heavier leg muscles than

Table 11

Yield of cuts and products $(\mathrm{kg})$

\begin{tabular}{|c|c|c|c|c|c|}
\hline Treatment & A & B & $\mathrm{C}$ & $\mathrm{D}$ & Effect of treatment $P$ \\
\hline Concentrate type & Conventional & Organic & Organic & Organic & \\
\hline Percent of concentrate & $100 \%$ & $100 \%$ & $70 \%$ & $70 \%$ & \\
\hline Fore-end & $11.55 \pm 0.07$ & $11.51 \pm 0.06$ & $11.66 \pm 0.06$ & $11.66 \pm 0.06$ & NS \\
\hline Loin & $7.75 \pm 0.05$ & $7.58 \pm 0.05$ & $7.64 \pm 0.05$ & $7.64 \pm 0.05$ & NS \\
\hline Belly & $6.13^{\mathrm{a}} \pm 0.06$ & $6.17^{\mathrm{a}} \pm 0.05$ & $5.89^{\mathrm{b}} \pm 0.05$ & $5.85^{\mathrm{b}} \pm 0.05$ & $<0.0001$ \\
\hline Leg & $11.02^{\mathrm{a}} \pm 0.05$ & $11.14^{\mathrm{ab}} \pm 0.05$ & $11.20^{\mathrm{b}} \pm 0.05$ & $11.26^{\mathrm{b}} \pm 0.05$ & $<0.05$ \\
\hline Loin without rind and bone & $3.30^{\mathrm{a}} \pm 0.04$ & $3.33^{\mathrm{a}} \pm 0.03$ & $3.46^{\mathrm{b}} \pm 0.03$ & $3.46^{\mathrm{b}} \pm 0.03$ & $<0.0001$ \\
\hline Belly without rind and bone & $4.59^{\mathrm{a}} \pm 0.04$ & $4.58^{\mathrm{a}} \pm 0.04$ & $4.31^{\mathrm{b}} \pm 0.04$ & $4.37^{\mathrm{b}} \pm 0.04$ & $<0.0001$ \\
\hline Leg round cut & $10.45^{\mathrm{a}} \pm 0.05$ & $10.53^{\mathrm{ab}} \pm 0.05$ & $10.62^{\mathrm{bc}} \pm 0.05$ & $10.73^{\mathrm{c}} \pm 0.05$ & $<0.01$ \\
\hline Leg muscles without rind, bone and fat & $6.73^{\mathrm{a}} \pm 0.07$ & $6.90^{\mathrm{b}} \pm 0.06$ & $7.14^{\mathrm{c}} \pm 0.06$ & $7.28^{\mathrm{c}} \pm 0.06$ & $<0.0001$ \\
\hline Tenderloin ( 2 pieces) trimmed & $1.16^{\mathrm{a}} \pm 0.01$ & $1.19^{\mathrm{ab}} \pm 0.01$ & $1.20^{\mathrm{ab}} \pm 0.01$ & $1.22^{\mathrm{b}} \pm 0.01$ & $<0.05$ \\
\hline
\end{tabular}

${ }^{\mathrm{a}-\mathrm{c}}$ Experimental treatments for the measured characteristics not sharing a common superscript letter within rows differ significantly. 
Table 12

Dimensions of cuts and products (mm)

\begin{tabular}{|c|c|c|c|c|c|}
\hline Treatment & A & B & $\mathrm{C}$ & $\mathrm{D}$ & Effect of treatment $P$ \\
\hline Concentrate type & Conventional & Organic & Organic & Organic & \\
\hline Percent of concentrate & $100 \%$ & $100 \%$ & $70 \%$ & $70 \%$ & \\
\hline Fat thickness loin & $18^{\mathrm{a}} \pm 0.1$ & $18^{\mathrm{a}} \pm 0.1$ & $14^{\mathrm{b}} \pm 0.1$ & $14^{\mathrm{b}} \pm 0.1$ & $<0.0001$ \\
\hline Circumference loin without rind and bone & $297^{\mathrm{a}} \pm 2$ & $301^{\mathrm{ab}} \pm 2$ & $305^{\mathrm{b}} \pm 2$ & $305^{\mathrm{b}} \pm 2$ & $<0.05$ \\
\hline Length loin without rind and bone & $544 \pm 4$ & $545 \pm 4$ & $545 \pm 4$ & $550 \pm 4$ & NS \\
\hline Length belly without rind and bone & $543 \pm 4$ & $545 \pm 3$ & $532 \pm 4$ & $537 \pm 3$ & NS \\
\hline Fat thickness leg round cut & $12^{\mathrm{a}} \pm 0.6$ & $12^{\mathrm{a}} \pm 0.6$ & $8^{\mathrm{b}} \pm 0.6$ & $8^{\mathrm{b}} \pm 0.6$ & $<0.0001$ \\
\hline
\end{tabular}

a,b Experimental treatments for the measured characteristics not sharing a common superscript letter within rows differ significantly.

Treatment A. Treatment D had heavier tenderloins than Treatment A.

In Table 12, the fat layer of both loin and leg was thicker for Treatments A and B than for Treatments C and D, and the circumference of the loin without rind and bone was larger for Treatments $\mathrm{C}$ and $\mathrm{D}$ than for Treatment $\mathrm{A}$. The lengths of the loin and the belly were not significantly different.

\section{Discussion}

Independent of treatments the overall performance of the pigs was good. Mean daily gain was $829 \mathrm{~g}$, and percentage of lean meat in the carcass was 60.7. No health problems appeared during the experimental period from $40 \mathrm{~kg}$ live weight until slaughter at a live weight around $108 \mathrm{~kg}$. Only 2 of the 160 pigs were discarded due to health problems or death during the experiment. A total of 154 pigs completed the production period according to the experimental plan, and 152 pigs completed all the meat quality measurements. Differences in live weight and warm carcass weight were based on the conditions of delivery to the abattoir at Research Centre Foulum. The pigs were slaughtered on only two days per trial, which in combination with the differences in daily gain between treatments will result in different live slaughter weight.

The minor but significant decrease in daily gain of Treatment B compared with Treatment A might be explained by access to the outdoor area for the pigs in the former treatment, potentially resulting in more exercise and a higher need for temperature regulation as the indoor temperature is more influenced by the outdoor temperature in productions systems with access to an outdoor area than in conventional systems.

The restricted concentrate feeding plus ad libitum roughages of Treatments $\mathrm{C}$ and $\mathrm{D}$ reduced daily gain of the pigs considerably compared with both Treatments A and $\mathrm{B}$ in accordance with previous experience (Danielsen et al., 2000). In restricted concentrate feeding treatments, daily gain decreased relatively more in the winter season compared with the summer season as opposed to the $100 \%$-concentrate treatments, and in contrast to the $100 \%$-concentrate treatments the castrated males showed lower daily gain than the females. These results indicate that a higher energy feeding level than $70 \%$ concentrate should be recommended for castrated male pigs during the winter season, not least when they are mixed with female pigs in the pen.

In contrast to daily gain, the feed conversion ratio based on net energy was not significantly different between treatments. However, the feed utilization was lower in the winter season, and although no significant interaction was found between treatment and season, the results seem to show that the restricted treatments had a better feed utilization in the summer time and a poorer in the winter season compared with the control-fed treatments. In accordance with previous results, the carcass quality expressed as percentage of lean meat increased in the restricted Treatments C and D compared with the $100 \%$-concentrate Treatments A and $\mathrm{B}$, and likewise the female pigs had a higher percentage of lean meat compared with castrated male pigs (Danielsen et al., 2000). As a consequence of the higher percentage of lean meat, Treatments $\mathrm{C}$ and $\mathrm{D}$ resulted in higher yields of products with high meat content (loin, leg, leg muscles and tenderloin) when corrected for slaughter weight, which also corresponded to thinner fat layers. In contrast, products from these treatments with a high fat content, e.g., the belly, had lower yields.

IMF was lower in loins from the restricted- and roughage-fed Treatments $\mathrm{C}$ and D compared with the control Treatments A and B, and pork from the female pigs had lower IMF compared with the castrated male pigs. As expected higher lean meat percentage is correlated to lower IMF regarding both treatment and sex.

The pigs seemed to prefer the clover grass silage in Treatment D compared with the barley/pea silage in Treatment $\mathrm{C}$ as the consumed amounts were $8.2 \%$ and $3.5 \%$, respectively, of the total energy intake in this experiment. The better quality of the clover grass silage could explain the higher energy intake (see Table 3). The higher intake of clover grass silage does not seem to be desirable as it results in a tendency to increased TBARS value and decreased vitamin $\mathrm{E}$ in muscle and liver of Treatment $\mathrm{D}$. The higher TBARS values of TreatmentsC and D and the lower vitamin E level of especially Treatment D corresponded to the higher energy intake of clover grass silage of Treatment $\mathrm{D}$, and the ensuing higher intake of polyunsaturated fatty acids was reflected in the meat and fat of the carcass (see Table 4). Increased oxidative susceptibility may present a problem in further processing of the meat and 
during production of convenience products (Sheard et al., 2000).

No difference in meat colour was registered as a function of the different treatments; however, the redness of the meat was higher during winter corresponding to higher pigment (myoglobin units) levels in muscles during winter.

The higher content of polyunsaturated fatty acids in Treatments C and D may not only be a result of the different feed but also partly caused by the higher lean meat percentage.

The differences in sensory attributes between treatments were minor except for the texture attributes. Although not as sensitive as the trained panellist, the average consumer may perceive meat from Treatments $\mathrm{C}$ and $\mathrm{D}$ to be less tender than meat from Treatments A and B. The decreased tenderness of meat from the restricted-fed pigs is in agreement with a previous report (Danielsen et al., 2000) and has been suggested to be due to a reduced daily gain, which results in slower muscle growth and slower protein turnover and hence a lower proteolytic potential in the meat (Therkildsen et al., 2002).

\section{Conclusion}

Our results demonstrate that organically produced pigs fed ad libitum concentrate without silage produce carcasses and meat of a high quality similar to pigs fed non organically. However, restricted feeding of organic cereals $(70 \%)$ plus silage ad libitum resulted in tougher meat with too little vitamin $\mathrm{E}$, although the carcasses were of higher quality with a lower fat content. The higher intake of polyunsaturated fatty acids in the organically fed pigs - both from organic concentrate and silage - was reflected in the meat and fat of the carcass. This may lead to rancidity and a WOF problem during storage and processing of the meat. This observation suggests that other methods of environmental enrichment and feeding systems are required to maintain meat quality under organic production systems.

\section{Acknowledgements}

The authors thank "Strukturdirektoratet" for financial support of this project. We also appreciate the assistance of manager Kjeld Mortensen, Rugballegaard and technical staff members, Jens Askov Jensen and Holger Thrane, DIAS, and Mianne Darré, DMRI.

\section{References}

Bligh, E. G., \& Dyer, W. J. (1959). A rapid method for total lipid extraction and purification. Canadian Journal of Biochemistry and Physiology, 37, 911-917.

Bridi, A. M., Müller, L., \& Ribeiro, J. A. (1998). Indoor vs. outdoorrearing of pigs. Performance, carcass and meat quality. In Proceedings of 44th Int. Cong. Meat Sci. Technol., Barcelona, Spain (pp. 1056-1057).

Claudi-Magnussen, C. (1999). (Organic pig production, comparison of organic and conventional retail meat products meat and eating quality). Report of 22nd September. Ref.nr.17.258/01 (0071.wpd). Danish Meat Research Institute, Roskilde., 1-28.

Danielsen, V., Hansen, L. L., Møller, F., Bejrholm, C., \& Nielsen, S. (2000). Production results and sensory meat quality of pigs fed different amounts of concentrate and ad lib. clover grass or clover grass silage. In Hermansen, J. E, Lund, V., Thuen, E. (Eds.), Ecological Animal Husbandry in the Nordic Countries. Proceedings from NJF-seminar No. 303 (pp. 79-86), Horsens, Denmark 16-17 September 1999.

Dworschak, E., Barna, E., Gergely, A., Czuczy, P., Hovari, J., Kontraszti, M., et al. (1995). Comparison of some components of pigs kept in natural (free-range) and large-scale conditions. Meat Science, 39(1), 79-86.

Enfält, A. C., Lundstrom, K., Hansson, I., Lundeheim, N., \& Nystrom, P. E. (1997). Effects of outdoor rearing and sire breed (Duroc or Yorkshire) on carcass composition and sensory and technological meat quality. Meat Science, 45(1), 1-15.

ESS-FOOD. (2005). Product catalogue. Available from: $<$ http://www.essfood.com/>. Randers, Denmark.

Hamm, U. \& Gronefeld, F. (2004). The European market for organic food: revised and updated analysis 5. (p. 165, Vol. 5). The OMlaRD series of publications.

Hansen, L. L., Bejerholm, C., Claudi, M. C., \& Andersen, H. J. (2000). Effects of organic feeding including roughage on pig performance, technological meat quality and the eating of the pork. In (Vol. Basel, Switzerland, 28 to 31 August, 2000. 2000, 288; 1 ref.), p. 288.

Honikel, K. O. (1996). Reference methods supported by OECD and their use in Mediterranean meat products. Food Chemistry, 59, 573-581.

Hornsey, H. C. (1956). The colour of cooked cured pork. I. Estimation of the nitric oxide-haem pigments. Journal of the Science of Food and Agriculture, 7, 534-538.

Jakobsen, K., \& Hermansen, J. E. (2001). Organic farming - a challenge to nutritionists. Journal of Animal and Feed Sciences, 10(Suppl. 1), 29-42.

Jaturasitha, S., Scheeder, M. R. L., \& Kreuzer, M. (1998). Free range pigs - quality of the products from the meat label 'Neuland'. I. Differentiation from common products. Fleischwirtschaft, 78(3), 261-265.

Jensen, S. K., Jensen, C., Jakobsen, K., Engberg, R. M., Andersen, J. O., Lauridsen, C., et al. (1998). Supplementation of broiler diets with retinol acetate, beta-carotene or canthaxanthin: effect on vitamin status and oxidative status of broilers in vivo and on meat stability. Acta Agriculturae Scandinavica, 48(1), 28-37.

Lebret, B., Massabie, P., Juin, H., Mourot, J., Chevillon, P., \& Ledenmat, M. (1998). Influence of pig housing conditions on muscular and adipose tissue traits, and technological and sensory quality of drycured hams. In Proceedings of 44th Int. Cong. Meat Sci. Technol. (pp. 1058-1059), Barcelona, Spain.

Lopez-Bote, C.J., Diestre, A., \& Monfort, J. M. (1998). Sustained utilization of the Iberian pig breed. Meat consumption and culture, 30 August-4 September 1998, Barcelona, Spain. 1998, 49(Suppl. 1, pp. S17-S27).

Lopez-Bote, C. J., \& Rey, A. I. (2001). Susceptibility of hepatic tissue of Iberian pigs is enhanced by free-range feeding and reduced by vitamin E supplementation. Nutrition Research, 21(3), 541-549.

Madsen, A., Petersen, J. S., \& Soegaard, Aa. (1990). Anatomic content of the female and castrated male pig fed according to scale or ad libitum and slaughtered at 20,50,80 or $110 \mathrm{~kg}$. Communication no. 769 (p. 4). National Institute of Animal Science (Denmark), DIAS.

Nilzen, V., Babol, J., Dutta, P. C., Lundeheim, N., Enfalt, A. C., \& Lundstrom, K. (2001). Free range rearing of pigs with access to pasture grazing - effect on fatty acid composition and lipid oxidation products. Meat Science, 58(3), 267-275.

Oksbjerg, N., Petersen, J. S., Sorensen, I. L., Henckel, P., Vestergaard, M., Ertbjerg, P., et al. (2000). Long-term changes in performance and meat quality of Danish Landrace pigs: a study on a current compared with an unimproved genotype. Animal Science, 71(1), 81-92.

Sather, A. P., Jones, S. D. M., Schaefer, A. L., Colyn, J., \& Robertson, W. M. (1997). Feedlot performance, carcass composition and meat quality of free-range reared pigs. Canadian Journal of Animal Science, 77(2), 225-232. 
Sheard, P. R., Enser, M., Wood, J. D., Nute, G. R., Gill, B. P., \& Richardson, R. I. (2000). Shelf life and quality of pork and pork products with raised n-3 PUFA. Meat Science, 55(2), 213-221.

Sundrum, A., Butfering, L., Henning, M., \& Hoppenbrock, K. H. (2000). Effects of on-farm diets for organic pig production on performance and carcass quality. Journal of Animal Science, 78(5), 1199-1205.

Tarladgis, B. G., Pearson, A. M., \& Dugan, L. Jr., (1964). Chemestry of the 2-thiobarbituric acid test for determination of oxidative rancidity in foods. Journal of Food and Agriculture, 15, 602-607.
Therkildsen, M., Melchior Larsen, L., Bang, H. G., \& Vestergaard, M. (2002). Effects of growth rate on tenderness development and final tenderness of meat from Friesian calves. Animal Science, 74, 253-264. Warnants, N., Oeckel, M. v., Boucque, C. V., \& van-Oeckel, M. J. (1996). Incorporation of dietary polyunsaturated fatty acids in pork tissues and its implications for the quality of the end products. Meat Science, 44(1-2), 125-144.

Warnants, N., Van Oeckel, M. J., \& Boucque, C. (1998). Effect of incorporation of dietary polyunsaturated fatty acids in pork backfat on the quality of salami*1. Meat Science, 49(4), 435-445. 